\title{
3 Following the movement of a pendulum: between universalism and relativism
}

\section{Marie-Bénédicte Dembour}

\begin{abstract}
Universalism and relativism are often presented as two opposite and irreconcilable moral (or epistemological) positions as regards human rights. Most often, the debate is phrased as if one should embrace either one or the other position. This chapter argues that these two positions cannot be considered independently of each other. Each is untenable by itself and needs to accommodate the other to be sustainable. The position I advocate, which encompasses both the universalist and the relativist stances, is not a middle position that would constitute a happy compromise, putting at rest, once and for all, the debate concerning the respective strengths of universalism and relativism. Rather it is a position which makes sense of the fact that a moral agent is inevitably drawn into a pendulum motion. Thus, as one accepts being drawn towards relativism, there is a moment when, getting as it were too close to it, one is compelled to revert towards universalism - and vice versa. My image of the pendulum indicates that the in-between position I advocate is unstable. That my position is characterized by instability does not imply that one should abandon striving to 'get things right', for example by drafting human rights legislation, but that one should pursue political struggles in awareness of the limitations that any achievement in this field, however remarkable, entail.
\end{abstract}

\section{Universalism as arrogance}

Exclusive claims to rationality and the ambition to attain a universal and uniform knowledge of the world characterized the eighteenth-century Enlightenment project if not always, at least in its French variant (Fitzpatrick 1992: 65). These enduring features are still noticeable in the way human rights are conceived today. This is confirmed to me each year I teach human rights courses to undergraduates. With a few exceptions, students take the existence of human rights international documents, agreed on by governments supposedly representing the whole world, as evidence that the human rights discourse sets universal 
standards which form a good basis on which to assess government action and, by extension, the way people behave towards each other. Such an attitude is consonant with a faith in natural law, which can be traced back in Western history to the very first manifestations of philosophical thought.

Through the centuries, at certain times more forcefully than at others, Western philosophers have put forward the idea that there exists a natural law. Despite significant variations, natural law philosophies share the following core characteristics: they rely on an absolute source (be it God, nature or the universe); they posit immutable and eternally valid principles (although the idea of a natural law with a changing content has been developed in the twentieth century); they assert that the content of natural law can be discovered through reason; and they conceive of natural law as taking precedence over positive law (Curzon 1979: 49).

For a good illustration of this position, we can turn to the following statement by Cicero (quoted in Harris 1980: 7):

True law is right reason on agreement with Nature; it is of universal application, unchanging and everlasting ... It is a sin to try to alter this law, nor is it allowable to repeal any part of it, and it is impossible to abolish it entirely . . . And there will not be different laws at Rome and Athens . . . but one eternal and unchangeable law will be valid for all nations and for all times, and there will be one master and one ruler, that is God, over us all, for us all, for he is the author of this law, its promulgator and its enforcing judge.

This passage was written around two thousand years ago. Modern manifestations of a belief in natural law include the American Constitution, which speaks of men endowed with rights 'by their Creator' and of 'self-evident truths', and the dominant contemporary concept of human rights, which conceives of these rights as being inherent to the human person.

Natural law is a problematic idea, however, in that it assumes that everyone will arrive at the same conclusion as to what is natural/natural law through an adequate exercise of reason. However, as anthropologists are aware, what appears natural to one person may not appear so natural to another. Not surprisingly, natural law theories have often, and rightly, been criticized for justifying the status quo by mistaking what is at the moment and therefore what we know, for what ought to be (Lloyds 1985: 92). Resort to reason in order to ground rights must always be treated with suspicion and its outcomes opened to review, because there is no guarantee that the reasoning of those resorting to reason is not faulty.

To turn again to my experience in the classroom, I asked my students 
one year, during our very first seminar, how they knew that universal human rights standards were good. One student answered: 'I just know it'. This, of course, is a reflection of how human rights are discovered and thus a perfectly adequate answer. But a second student immediately intervened: 'Yes, but what you find good may not be what other people find good'. She added by way of illustration: 'I feel strongly about the need not to discriminate against homosexuals, but my grandmother does not see it that way'. The second student would easily understand that what a society conceives as 'natural' is often nothing else than what happens to be 'mainstream'.

It is also important to realize that human rights do not make sense outside the specific political and social history from which they have evolved, which can be summarized as the struggle to check the arbitrariness of the modern state. Tore Lindholm (1998) suggests that speaking of human rights before 1948, the year the UN Universal Declaration was signed, is an anachronism. I could not agree more with him, even if we recognize that the tradition from which the human rights discourse has evolved is a long and enduring one.

The core reason for my resistance to a universal position, however, lies elsewhere. By positing the existence of universal values which can be discovered through reason, the human rights discourse can too easily engender arrogance. One definition the Shorter Oxford English Dictionary provides for the latter term is 'undue assumption of knowledge'. An approach convinced of the righteousness of human rights standards must ultimately lead to arrogance because it excludes the experience of the 'other'. This is why I always try to shake the righteous beliefs of those students who readily embrace the view that human rights are universal and encourage them to remain sceptical of what they think they know. In other words, I try to instil in them an awareness of cultural relativism. If I speak of 'awareness' in the last sentence, it is because both the concept of culture and the idea of relativism underlying 'cultural relativism' are problematic, as I shall now explain.

\section{Relativism as indifference}

I have made clear that I am wary of universalism. This does not entice me to its supposed opposite, which rejects the idea of the universality of human rights to embrace a cultural relativist position. The thrust of this latter position is to argue that human rights entail negative comments upon other cultures - unjustifiably, since each culture has its own moral values. This argument is problematic on more than one count.

First, what concept of 'culture' underlies a cultural relativist position? 
As pointed out in the introduction and by various contributors to this volume, cultures and societies are never as homogeneous as they appear. Quite commonly, the term culture is used to refer to a traditional mode of living shared by a group, in a way that fails to take into account historical change and the absence of completely fixed boundaries around any human group. Cultural relativism tends to assume that people are more determined by their culture than they in fact are. This is problematic because individuals are boxed in a mode which is presumed to suit them, closing them off from avenues they may have preferred to embrace.

A second problem with cultural relativism is that it often posits a stark ideological divide between the collectivism of would-be 'traditional' societies and the individualism of the West. The argument runs that the individual logic of the human rights ideology does not suit the more communatarian logic of non-Western societies (see Pollis \& Schwabb 1980). This is to forget that even these societies recognize the purposeful agent (a term possibly more adequate than the 'individual', which tends to connote a Western subject endowed with rights and duties) and the need for his or her protection. ${ }^{1}$ The stark divide posited between the West and the rest of the world just does not exist.

Following from this, cultural relativism obscures the fact that the spread of the modern state makes human rights relevant throughout the world. ${ }^{2}$ I ask the few students who fiercely contest the value of universal human rights in my classroom whether they think that opponents who face execution in a dictatorial state would accept that the fact that they are from a non-Western culture invalidates their claims for human rights protection. I try to tell them: 'Feel something, and say something!' In other words, I ask them to resist a cultural relativist position which can make moral agents indifferent to immoral situations. As Elvin Hatch has recently observed, 'this position may lead to moral neutrality and inaction in situations that are intolerable' (Hatch 1997: 372). From a relativist perspective, culture easily becomes an excuse for abuse.

Of course all that I have said so far means that we are in a conundrum. On the one hand, I have suggested that the adoption of a cultural relativist position can foster unjustifiable indifference. This directs us back to the idea that some values must be universal. On the other hand, I have observed in the previous section that for anyone to believe that the values he or she holds are universal is dangerous, because it leads easily to arrogance. I shall argue that the one way out of this conundrum is to err uncomfortably between the two poles represented by universalism and relativism. 
Before examining how to do this, it is worth asking whether some situations are so obviously clear-cut that we should not err in between but should adopt a universalist position. Hatch asserts that 'political executions, genocide, genital mutilations, honour killings, and the like' are 'situations in which ethical relativism is untenable' (ibid). This may well appear so. However, in respect to female genital mutilation, which happens to be the one area on Hatch's list in which I have done some research, ${ }^{3}$ I would dispute his claim. This makes me think that a universalist position must always be approached with caution. I shall indeed argue that a cultural relativist position often creeps, unrecognized, into universalist discourses. Before making this point, let me first explain in what sense female genital mutilation is not a clear-cut case which allows us to choose firmly between universalism and relativism. ${ }^{4}$

\section{Erring uncomfortably in-between: female circumcision as an unlikely illustration}

Through activists' writings, the Western world has become increasingly aware since the 1970s that women inhabiting some parts of Africa have had for centuries, and continue to have, their daughters circumcised as a matter of course (Thomas 1996: 339 and references cited). Speaking of circumcision in this context is most often an euphemism. The term designates an array of practices which range from - rarely - the removal of the prepuce (circumcision in the proper sense of the term), to the ablation of the clitoris (excision), to the cutting of the labia, which are left to heal through scarring while a small hole is maintained for the passage of urine and menstruation (infibulation). To a Western sensitivity, the very idea that such operations are performed on young women and even infants sends shivers down the spine and fills one with horror. How can this be possible?

Those who practice female circumcision generally invoke tradition to justify the practice. They say they do it because 'it has always been done'. Pressed to elaborate, they cite religious, health and sexual reasons. Some groups, for example, believe that circumcision makes the woman clean, or that it enhances her fertility, or that it protects her future babies against a perceived lethal danger of the baby coming into contact with female genitals. ${ }^{5}$ All these justifications do not stand up to Western rationality and sensibility, which see these operations as maintaining the subordination of women to men in an appalling and healthdamaging way. Outright condemnations of these practices abound in the West. ${ }^{6}$

However, for the great majority of women born into the societies 
concerned, circumcision is what makes a woman a woman. These women cannot envisage not circumcising their daughters, despite the pain they thereby inflict upon them, because they know that otherwise their daughters would never become proper women, and would fail to find husbands later in life. Of course, we can dispute this knowledge from a Western perspective. But if we accept the idea of looking at the world from the perspective of these women, we can see why the practice is so resilient to efforts undertaken to eradicate it. We can also understand why migrant populations from the societies concerned continue to have their daughters circumcised even when they are living in a completely different environment (Touré 1994). In what follows I shall concentrate on what has happened in France, for the way things have developed there illustrates particularly well how one cannot squarely side with either a universalist or a relativist position.

France presents itself as le pays des droits de l'homme - the land of human rights. ${ }^{7}$ The French Revolution marked a shift from a political system based on status and privilege to one which declared liberty and equality as its founding principles. The French political system was and continues to be seen by the French as embodying universal values. In this view, what makes someone French is her or his adherence to the values of the Republic, conceived as universal. Anyone can become French as long as he or she recognizes these values, but those who embrace different values cannot be truly French. Hence there is an overall tendency in contemporary migrant French policies towards integration (some would say assimilation), rather than towards recognition of difference (through 'multiculturalism') (Hargreaves 1995: 160-164; Favell 1998, ch. 3).

Considering this background, it is not surprising that France finds it difficult to accommodate, or even to ignore, the practice of female circumcision on its territory by migrant populations. In France, criminal cases have been brought against mothers and fathers who have had their daughters circumcised, as well as against women thought to have performed the operation (exciseuses). No other country in Europe has followed this route of instigating lawsuits, even though female circumcision is practised wherever there are migrant populations from regions where the practice is prevalent. The fact that such practices occur is well-known, and explains why Britain and Sweden, among others, have adopted laws which specifically criminalize female circumcision (Toubia \& Rahman 2000). While in France no specific law has been passed, a number of prosecutions based upon general laws on assault have occurred. They have met with mixed results.

The cases have been directed mainly against Soninke and Bambara 
women, many of whom arrived in France around 1980. The story of Bobo Traoré made the headlines in July 1982. Bobo died, aged three months, in Créteil, near Paris. The autopsy revealed that there was no blood left in her body. The explanation was that she had been excised two days before. Despite the obvious complications, her father had decided not to take her to hospital, fearing that what he had done would be considered illegal in France. Following the media outcry, public prosecutors begun to bring out similar cases upon which they had not acted.

A number of prosecutions ensued. Five cases were brought up before correctional tribunals between 1982 and $1987 . .^{8}$ The fact that the French correctional tribunal is competent to hear cases that can result in a sentence of up to five years' imprisonment indicates that an excision was not originally conceived as an offence likely to lead to a very severe sentence. The conviction of the father of Bintou Doukara, who suffered a relatively minor haemorrhage, is typical of this first wave of prosecutions. Mr Doukara was tried for voluntary assault on a child under fifteen years of age and received a one-year suspended sentence. ${ }^{9}$ Interestingly, the Prosecutor himself had requested the suspension of the sentence. This suggests some discomfort on his part at handling the prosecution - a fact to which I shall return.

A shift in the history of the excision trials occurred in May 1986 when the correctional tribunal declared itself non-competent to hear the Coulibaly/Keita case, brought against the parents of six daughters, as well as the exciseuse. In July 1987 the Court of Appeal confirmed the decision of non-competence by the correctional tribunal, accepting the argument put forward by the parties civiles, ${ }^{10}$ but rejected by the Prosecution, that proceedings related to the cutting of the clitoris were within the jurisdiction of the assise court (competent for the most serious crimes), as opposed to that of the correctional tribunal (competent for less serious crimes). To understand this development, it is necessary to mention a case which concerned an excision in the technical sense of the term but which had nothing to do with custom and culture.

In August 1983, a French woman, Danièle Richer, who had no African connection, was convicted by an assise Court in Britanny for having sadistically cut the clitoris of her daughter. The Court had applied Article 312 of the penal code, which provided that any voluntary violence upon a child of under fifteen years of age was to be punished by imprisonment of between ten and twenty years if mutilation, permanent disability or unintentional death resulted. The parties civiles in the migrant cases argued that an excision being always an excision, the Richer case constituted a precedent to be followed in the subsequent 
Table 3.1 Basic information on the French excision trials ${ }^{\mathrm{a}}$

\begin{tabular}{|c|c|c|c|}
\hline $\begin{array}{l}\text { Date } \\
\text { Tribunal location }\end{array}$ & $\begin{array}{l}\text { Defendant's name } \\
\text { (status) }\end{array}$ & Incriminated excision & Sentence or other outcome \\
\hline $\begin{array}{l}11.1979 \\
\text { Correctionel Paris }\end{array}$ & Unknown (exciseuse) & $\begin{array}{l}\text { Performed in June } 1978 \text { on a } 3 \text {-year-old } \\
\text { who dies as a result }\end{array}$ & 1 year suspended \\
\hline $\begin{array}{l}10.1982 / 4 ? \\
\text { Correctionel Paris }\end{array}$ & $\begin{array}{l}\text { F. Doukara } \\
\text { (father) }\end{array}$ & $\begin{array}{l}\text { Performed on } 3 \text { month-old Bintou who goes } \\
\text { for two weeks to hospital }\end{array}$ & 1 year suspended \\
\hline $\begin{array}{l}08.1983 \\
\text { Cassation Court }\end{array}$ & $\begin{array}{l}\text { D. Richer } \\
\text { (mother) }\end{array}$ & $\begin{array}{l}\text { Performed by the accused who was French } \\
\text { and insane }\end{array}$ & Unknown \\
\hline 1984 Correctionel Paris & Unknown & Resulted in death & 1 year suspended \\
\hline $\begin{array}{l}1984 \\
\text { Correctionel Paris }\end{array}$ & Traoré (father) & $\begin{array}{l}\text { Performed in July } 1982 \text { on 3-month-old Bobo } \\
\text { who died as a result. Media outcry }\end{array}$ & $\begin{array}{l}\text { Declaration of incompetence } \\
\text { (upheld in appeal) }^{\mathrm{b}}\end{array}$ \\
\hline $\begin{array}{l}05.1986 \\
\text { Correctionel Paris }\end{array}$ & $\begin{array}{l}\text { Coulibaly (parents) / } \\
\text { A. Keita (exciseuse) }\end{array}$ & $\begin{array}{l}\text { Performed in } 1982 \text { and } 1983 \text { on six sisters } \\
\text { aged } 16 \text { months to } 8 \text { yrs }\end{array}$ & $\begin{array}{l}\text { Declaration of incompetence } \\
\text { (upheld in appeal in July 1987) }\end{array}$ \\
\hline 1987 Correctionel ? & Unknown & Resulted in death & 2 years suspended \\
\hline $\begin{array}{l}05.1988 \\
\text { Assise Pontoise }\end{array}$ & $\begin{array}{l}\text { Baradji (father and two } \\
\text { wives) }\end{array}$ & $\begin{array}{l}\text { Performed in April } 1983 \text { on Mantessa a few } \\
\text { weeks-old, who died as a result }\end{array}$ & 3 years suspended \\
\hline $\begin{array}{l}10.1989 \\
\text { Assise Pontoise }\end{array}$ & D. Fofana (mother) & $\begin{array}{l}\text { Performed in June } 1984 \text { on week-old Assa } \\
\text { who suffers a minor infection as a result }\end{array}$ & 3 years suspended \\
\hline $\begin{array}{l}06.1990 \\
\text { Assise Bobigny }\end{array}$ & Soumaré (father) & Objected to by French mother afterwards & 3 years suspended \\
\hline $\begin{array}{l}03.1991 \\
\text { Assise Paris }\end{array}$ & $\begin{array}{l}\text { Coulibaly (parents) / } \\
\text { A. Keita (exciseuse) }\end{array}$ & (See above) & $\begin{array}{l}\text { Parents: } 5 \text { years suspended } \\
\text { Exciseuse: } 5 \text { years }\end{array}$ \\
\hline $\begin{array}{l}06.1991 \\
\text { Assise Bobigny } \\
\text { (closed trial) }^{\mathrm{c}}\end{array}$ & $\begin{array}{l}\text { Unknown (high } \\
\text { number of parents) / } \\
\text { A. Keita (exciseuse) }\end{array}$ & 16 excisions, one leading to death & $\begin{array}{l}3 \text { fathers: acquitted } \\
\text { mothers: } 1 \text { year suspended } \\
\text { Exciseuse: } 4 \text { years, } 1 \text { of which suspended }\end{array}$ \\
\hline 01.1993 Assise Paris & T. Jahate (mother) & Performed on two sisters & 5 years, 4 of which suspended \\
\hline 01.1993 Assise Bobigny & K. Diane (mother) & (Contested) infibulation on a month-old baby & 5 years suspended \\
\hline
\end{tabular}


Table 3.1 contd.

\begin{tabular}{|c|c|c|c|}
\hline $\begin{array}{l}\text { Date } \\
\text { Tribunal location }\end{array}$ & $\begin{array}{l}\text { Defendant's name } \\
\text { (status) }\end{array}$ & Incriminated excision & Sentence or other outcome \\
\hline $\begin{array}{l}02.1993 \\
\text { Assise Paris }\end{array}$ & $\begin{array}{l}\text { Camara (father and two } \\
\text { wives) }\end{array}$ & & $\begin{array}{l}\text { Father: } 4 \text { years suspended except for } \\
1 \text { month. His wives: } 3 \text { years suspended }\end{array}$ \\
\hline $\begin{array}{l}02.1993 \\
\text { Assise Paris }\end{array}$ & $\begin{array}{l}\text { T. Traoré and K. Doukoré } \\
(2 \text { mothers and friends) }\end{array}$ & $\begin{array}{l}\text { Performed on two girls, one } 2 \text {-year-old and } \\
\text { one } 3 \text {-year-old, one of whom requires } \\
\text { hospital treatment }\end{array}$ & 5 years suspended \\
\hline $\begin{array}{l}04.1993 \\
\text { Assise Bobigny }\end{array}$ & $\begin{array}{l}\text { Abd. Keita (husband and } \\
\text { accomplice of exciseuse) }\end{array}$ & Involved in 4 excisions & 4 years, one of which suspended \\
\hline $\begin{array}{l}06.1993 \\
\text { Assise Paris }\end{array}$ & A. Tandian (mother) & $\begin{array}{l}1989 \text { excision, denounced through } \\
\text { anonymous call to PMI (medical centre) }\end{array}$ & 3 years, 2.5 of which suspended \\
\hline 09/10.1993 Assise Paris & B. Fofana (mother) & & 5 years suspended \\
\hline $\begin{array}{l}09.1993 \\
\text { Assise Paris }\end{array}$ & $\begin{array}{l}\text { Unknown (mother and } \\
\text { father) }\end{array}$ & & 1 year suspended \\
\hline $\begin{array}{l}01.1994 \\
\text { Assise Bobigny }\end{array}$ & $\begin{array}{l}\text { Unknown (mother and } \\
\text { father) }\end{array}$ & $\begin{array}{l}\text { Performed in } 1989 \text { and signalled by a } \\
\text { doctor }\end{array}$ & $\begin{array}{l}\text { Mother: } 2 \text { years suspended } \\
\text { Father: } 1 \text { year suspended }\end{array}$ \\
\hline $\begin{array}{l}09.1994 \\
\text { Assise Paris }\end{array}$ & $\begin{array}{l}\text { A. Traoré (mother), } \\
\text { S. Diarra (father)/ } \\
\text { H. Gréou (exciseuse) }\end{array}$ & Performed ten years before & $\begin{array}{l}\text { Parents: acquitted } \\
\text { Exciseuse: } 1 \text { year suspended }\end{array}$ \\
\hline $\begin{array}{l}02.1999 \\
\text { Assise Paris }\end{array}$ & $\begin{array}{l}\text { Koita (mother), } 32 \text { other } \\
\text { mothers and } 3 \text { fathers / } \\
\text { H. Gréou (exciseuse) }\end{array}$ & $\begin{array}{l}\text { HISTORY UNKNOWN BY AUTHOR } \\
\text { Some } 50 \text { excisions, one of which denounced } \\
\text { by the grown-up daughter of Mrs. Koita }\end{array}$ & $\begin{array}{l}\text { Mrs Koita: } 2 \text { years. The } \\
\text { other parents: suspended. } \\
\text { Exciseuse: } 8 \text { years }\end{array}$ \\
\hline
\end{tabular}

\footnotetext{
a The sources consulted are not always consistent regarding dates, spelling of names, and the kind of information provided.

b In 1986 the father was sentenced to a two-year sentence. He later went insane.

c Due to a defendant having been a minor at the time of the excision.

d However, the conviction was not to appear on Mrs. Keita's casier.

Sources: Weil-Curiel (interviews), Winter 1994, Lefeuvre-Déotte 1997 and Le Monde (1989-1993).
} 
cases of excision involving Africans. Their reasoning was that any discrimination between different types of excision would be racist because it would leave girls of African origin unprotected from mutilation. This is the argument that prevailed before the correctional tribunal in 1986 and before the Court of Appeal in 1987. Since then, excision cases have always been brought under Article 312 of the penal code. As a result, they have been heard by assise courts from 1988 onwards. To this day, the two assise courts before which most excision cases have been brought are those of Paris and Bobigny.

The French assise court is constituted by three professional judges and a jury of nine citizens. The procedure is entirely oral. A verdict of condemnation is reached when at least eight of the twelve persons constituting the bench vote in this direction. In the case of the excision trials, commentators have remarked that the atmosphere in the courtroom was less reminiscent of a legal trial than of an academic colloquium or a political debate. This was because it is not so much the details of a particular case which are debated as the general issue of the practice of excision. In excision trials the same arguments are repeated from one trial to the next, although obviously before a different jury; the same experts (including Michel Erlich and Claude Meillassoux) say basically the same thing. Linda Weil-Curiel, who has represented a partie civile in more than twenty of these cases told me she found these audiences tedious. For her, what is being said in the one or two days of the trial has become highly predictable.

Three main arguments can be identified on the side of the Prosecution and the parties civiles. First, given that the facts are generally not disputed, the main question is whether the accused knew they were acting against the law. The answer is that they did. Second, all sane citizens are legally responsible for their acts. The force of custom must give way before the law and the act of excision can therefore not be condoned. Third, France has a duty to protect all its children, irrespective of their colour. Failing adequately to react would be both immoral and racist.

The defence also puts forward three main arguments. First, the parents are not criminals. Not only did they not intend to hurt their child, from their perspective, having the excision performed is an act of love. While the act is criminal, the criminal intention - the moral element of the infraction - is absent. Second, the accused were acting under the constraint of a powerful custom. Even if they were aware that what they were doing was illegal in France, they could not take in and act upon this information. Third, imprisoning a mother - the most likely defendant - only makes the situation worse for the children. 
There is insufficient space here to show how these arguments are elaborated in the courtroom. ${ }^{11}$ However, the argument that the mother regards excision as an act of love deserves more attention. As we have seen, female genital mutilation is commonly considered as marking one of the limits of cultural relativism. This is so even for an anthropologist such as Hatch, whose general argument is in defence of relativism. Interestingly, Hatch does not explain his position, as if it goes without saying that female genital mutilation offends universal principles. If this is so, it is presumably because, from a Western perspective, female circumcision brings about gratuitous suffering, affecting children for the rest of their life, in an irreversible way.

In this light, the argument that excision is an act of love appears aberrant. Indeed, female circumcision is generally regarded by outsiders to the societies concerned (and, rarely, by insiders, too) as an act of cruelty - hence its other, and many would argue more proper, denomination as female genital mutilation. Witness an article in The Big Issue (September 29 - October 5 1997) entitled 'The Unkindest Cut'. Its point was precisely to protest against the use of the term 'circumcision' to designate mutilatory practices. Cruelty runs as a leit-motif in the relevant literature. ${ }^{12}$ However, a different image emerges from accounts which attempt to give a voice to the mothers directly concerned, and in which it becomes clear that mothers have their daughters circumcised, in perfect awareness of the pain inflicted, not out of cruelty but to enable their daughters to have a future as women. A striking illustration of this reasoning is provided by the mother who decides not to have her youngest daughter circumcised because the girl has Down's Syndrome and would not be marriageable anyway (reported in Lightfoot-Klein 1989: 264). ${ }^{13}$

This aspect is often lost on Western audiences. As I was waiting to interview Linda Weil-Curiel in the Paris Court of Justice, one of her clients, a French middle-aged man accused of some business misdemeanour, hearing I was doing some research on the excision trials, exclaimed: 'These things are awful. How can anyone do that to little girls and one's own at that? These people must be jailed'. The horror he expressed not only towards the act of circumcision but also towards the persons apparently directly responsible for it, is one that I expect is widely shared in French society (and beyond). My feeling is that the nine members of the jury selected to decide each excision trial often think at the outset that the issue is straightforward. If I am right, the outcomes of the trials indicate that their views change in the course of the judicial debates. ${ }^{14}$

Trials have generally been directed against the mothers of the excised 
girls because fathers can often demonstrate that they were not physically present at the excision and therefore argue they had nothing to do with it (which, strictly speaking, is often true as the operation is typically arranged and performed by women). As for the exciseuses, their identity is rarely revealed, which allows them to escape the judicial process altogether. Major exceptions concern Aramata Keita and Hawa Gréou, who have each been tried more than once and have consistently been dealt with more severely than parents.

The first trials ended with suspended sentences, slightly increasing through time, for the parents (usually mothers) concerned. The suspended sentences were initially of one year (up to 1984), then of two years (1987) then three years (from 1988 to 1990), and subsequently again (in March 1991) five years' imprisonment. In January 1993 a mother was sentenced for the first time to serve part of her sentence (one year of a five-year sentence).$^{15}$ By that time, two sentences of imprisonment had already been pronounced against an exciseuse, A. Keita. The pattern of steadily increasing severity then stopped. The other trials which took place in 1993 and early 1994 resulted in sentences of various lengths, which were suspended, although not always in their entirety. A striking development in the history of the excision trials occurred in September 1994 when the parents were acquitted. In this same trial, which dealt with an excision performed ten years earlier, the exciseuse, $\mathrm{H}$. Gréou, received a one-year suspended sentence. While I do not know the outcomes of the following trials, it is clear that this lenient trend was fiercely reversed in February 1999 when a mother, indirectly denounced to the police in 1994 by her then grown-up daughter who had brought a complaint against her exciseuse, was condemned to serve two years in prison. In this last trial, the exciseuse, Mrs Gréou, was condemned to eight years in prison for performing some fifty circumcisions on young girls belonging to a large number of families. The other parents - twentythree mothers and three fathers - received suspended sentences.

If the debates taking place in the courtroom are predictable for those accustomed to them, the verdicts are not. The wide spectrum of verdicts includes one acquittal, but also firm sentences of imprisonment. In the great majority of cases, however, the trials have led to suspended sentences, as if the courts could condone neither the consequences of an acquittal nor those of an imprisonment. Expressing a conundrum, these suspended sentences can be seen as reflecting the adoption of a mid-way position between the relativism and the universalism respectively entailed by an acquittal and a firm condemnation. Contrary to what this last proposition suggests, however, the adoption of a universalist position need not necessarily lead to a sentence of imprisonment. 
Conversely, an acquittal does not necessarily mean the adoption of a cultural relativist position.

It is possible to be against excision as a practice and to identify it as a human rights violation without calling for its criminalization. Thus, when the Inter-African Committee on Traditional Practices Affecting the Health of Women and Children, which strives to eradicate female genital mutilation in Africa, heard about the sentencing of Teneng Jahate in the January 1993 trial, it expressed its 'alarm and concern' in a letter addressed to the French Ministry of Health, Social Affairs and Integration. ${ }^{16}$ The Committee appealed for the case to be handled with compassion, arguing that the last thing children needed was the 'double punishment of first being mutilated and then separated from their mother'. This reaction indicates that a criminal conviction was not regarded as an option by an organization whose antipathy for the criminalized practice (as opposed to its practitioners) is not in doubt.

In the same way that universalism and imprisonment need not go together, an acquittal does not necessarily represent an expression of cultural relativism. The motivation for the acquittal may lay in an awareness of the plight of the women concerned, in a refusal to treat them as criminals. In this case, the acquittal does not entail any respect for the values embodied by excision. Nonetheless, it may not be the impression which emerges from an acquittal verdict. When I met Linda Weil-Curiel in March 1997, she still regarded the acquittal of the couple Traoré-Diarra in September 1994 as a major setback in her fight against female genital mutilation. ${ }^{17}$ She worried that it sent the wrong message to migrant African populations who would think that it was now acceptable to circumcise their daughters in France.

While not dismissing her reading of the 1994 acquittal, I tend to see it in a different light. To me, the acquittal shows that the French judiciary, which had adopted an increasingly severe stance in the late 1980s and early 1990s, felt uncomfortable with the consequences of its stance. Applying my image of the pendulum, one can speculate that, having gone too far in one direction, it was driven to revert back towards leniency. It is as if the French, renowned for believing in the values of their Republic and France, the first country in Europe to have instigated criminal proceedings over female circumcision, were unable to draw the logic of their reasoning to its conclusion. However, one senses that a judgement of acquittal is unsatisfactory. As Linda Weil-Curiel remarks, it sends the wrong message. This in turn can explain the strict condemnations of 1999, which would signal an opposite movement of the pendulum.

Interestingly, when I met her, Weil-Curiel reflected that, when they 
grew up, the girls who had been excised in France would ask why the country in which they were born had done nothing to protect them. In fact, as I have already stated, the February 1999 trial was initiated by Mariatou Koita, who reported her excision to the police when she reached adulthood. Mariatou's action, arguably to be understood by reference to the fact that she spent some years in a French family, nevertheless indicates that culture should never be seen as set in stone. In the light of culture's flexibility, the recent return of the French judiciary to severe sentencing can be welcomed as offering, if not actual protection, at least some recognition of the girls' plight. But the judicial reversal is not wholly satisfactory either, as it sends to jail women whose predicament, not only in the cultural sphere but also from a social and economic point of view, should attract sympathy rather than blame. This is why I expect the recent condemnations not to constitute the end of the story. There will probably be further trials, whose outcomes will continue to follow the movement of a pendulum.

Judges and jurors do not speak with one voice, as the variety of verdicts pronounced from one trial to the next indicates. This, I would suggest, must be because uncertainties creep in as they begin to hear the other side of the issue. This is so even though they cannot hear the latter very clearly. The accused must feel at a loss in the grand surroundings of the courtroom where their fate is being decided, but where they often cannot follow the debates closely, French being a language in which they generally lack fluency even though it may be the official language of their country of origin. However, their answers to the court's questions, relayed by translation, as well as the testimonies of anthropologists and other experts, start to shake the assumptions with which the jury entered - or so I suspect - the courtroom. Jurors hear that the women concerned love their children and that excision does not always mean the absence of sexual pleasure, even orgasm in some cases. Perhaps they start to reflect that the position of Western women is not always enviable either, even if constituting a different predicament. They are asked to condemn women whose cultural assumptions are different from their own, but they are no longer sure what entitles them to do so.

This explains the suspended sentences and the acquittal. But these decisions do not represent the triumph of cultural relativism. What lies behind them is the awareness that general principles (whether phrased in legal language or in terms of human rights) do not do justice to the complex reality, and need to be 'relativized' in view of the circumstances of particular cases. What these decisions also signal is the demise of the arrogance - or undue assumption of knowledge - of the universalist position. 


\section{An in-between position, not a via media}

The French material shows that an apparent simple truth - that female genital mutilation is horrific and must be punished - turns out not to be so simple. The problem with the truth is that if I believe in the truth, of course I believe that it is the truth; I believe that I am right, full stop. In other words, believing in the truth can all too easily lead one unduly to assume one knows best, i.e. to arrogance. To quote Raimundo Panikkar (1982: 93-94):

Truth has the inbuilt claim to be universally valid, here and there, yesterday and tomorrow, for you and for me. Yet my grasping and formulating it cannot sustain the same claim without charging all the others who do not agree with me with stupidity or wickedness. Hence the necessary via media between agnostic relativism and dogmatic absolutism.

Panikkar wishes to relativize the truth - what I have called the arrogance - of human rights, without rejecting altogether the ideal they represent and adopting a nihilist position (what I have called indifference). $\mathrm{He}$ recommends finding a via media. Initially, I agreed with him. After further reflection, I now think that the in-between position I recommend has little to do with Panikkar's via media. However, it is worth reviewing what he has to say because his essay is one of the most illuminating in the existing literature on the implications of the Western origin of the human rights concept.

Panikkar conceives of human rights as one window on the world, i.e. one vision, one way of trying to install justice. His point is that there can be other windows, visions, ways of trying to achieve the same ideal. He thus recommends that we look for functional equivalents to human rights in non-Western societies (ibid.: 77-79), ${ }^{18}$ through 'good manners' or $l i$ in Confucian culture, for example (ibid.: 78), or Svadharma in India (ibid.: $95-100) .{ }^{19}$

We must accept that there are a number of worthwhile visions of how to achieve human dignity. The problem is that the human rights discourse tends to think of itself as the only one. In my words, it leads to arrogance. In Panikkar's words, it leads to blindness. To quote him: 'Human rights are one window through which one particular culture envisages a just human order for its individuals. But those who live in that culture do not see the window'. He continues:

For this they need the help of another culture which sees through another window. Now I assume that the human landscape as seen through the one window is both similar to and different from the vision of the other . . (ibid.: 78-79)

This passage reminds me of a garden I am particularly fond of. The 
garden looks completely different, and yet the same, whether one looks at it from a window on the ground floor or from one on the second floor. The same goes for moral philosophies to the extent that they cannot conceive of other, equally valid, visions.

Our particular case is a typical example of the pars pro toto: from the optic of the inside it looks like the whole; from the outside it looks like a part, a fragment. Similarly, Human Rights are universal from the vantage point of modern Western culture, and not universal from the outside looking in . . .

The answer which claims to discover the totum in parte is appealing, but not convincing. This is the temptation of the intellectual, who senses that any affirmation has the inbuilt tendency to be universally valid . . .

Here lies the crux. We cannot but aim at the totum, and yet we often forget that all we see is the pars which we then take pro toto. (ibid., 94).

Panikkar asks us not to forget that our truth is not the whole truth. The best way to do this, he says, is to engage in a dialogue with the 'other', who will tell us his or her truth. In his words (ibid: 95), 'In brief, we need [to engage] in a dialogical dialogue . . . We must accept what our partner tells us: simply that we take the totum pro parte, when we are aware of the pars pro toto'.

We think we understand the position women who have excision performed on their daughters are in and what is best for them, but do we? Melissa Parker (1995) wonders whether it is the way we conceive of and practice sexuality in the West that leads us to an obsession with denouncing what we call female genital mutilation. Hazel Summerfield (1993) suggests that the infibulation of Somali women in London may represent the key to their relatively good mental health, because they are allowed more freedom of movement than their Bangladeshi counterparts. Rhoda Howard (1993) points out that Western women do not have solutions to the problems associated with sexuality, as the incidence of anorexia demonstrates, for example. We should be wary of pronouncing judgements on other people's ways. At least we should not assume that we necessarily know better than they do.

This is not to say that we should be against human rights. Panikkar, for one, is not. On the contrary, he concludes his essay by saying that their defence constitutes a 'sacred duty' in the contemporary political arena (Panikkar 1982: 101). However, he urges more room for other world traditions, and hopes for the creation of an 'intermediary space' that would help bring forth, through a 'dialogical dialogue', the construction of a 'new myth'. While I agree with him that it is crucial to engage in a dialogue and not to assume that we know the 'other' before we have talked or listened to him or her, I am less convinced by his suggestion of a new myth in an intermediary space. Such a myth, I 
think, would only displace the problem. I suggest that we need to accept the discomfort of moving in-between, as a pendulum. In this sense, Panikkar's via media is different from the unstable in-between position that I advocate.

The difference in our perspectives probably stems from the fact that we are not talking about the same thing. Panikkar has in mind the very concept of human rights and its alternatives around the world. $\mathrm{He}$ is talking all along about principles and moral norms. He is not concerned with the dilemma French judges and juries face when they have to decide whether parents who have had their daughters excised should be condemned or deserve sympathy, with the flux between being drawn towards the universal and back to the particular again. What he seems to be after is the meeting of two would-be universals. ${ }^{20}$ The same interest guides Corine Kumar (1998) when she talks of culture as a real alternative to human rights formulations and forgettings. She tells us that culture can be good, that it need not be conceived as something which mitigates or even annihilates human rights. By contrast, when I try to understand why women are driven to have their daughters excised or when Heather Montgomery (in this volume) discusses what prompts Thai children to prostitute themselves to Western men, we are questioning how principles can (or cannot) get applied. In other words, we are looking at the interface between principle and practice.

In other words, my aim is not to suggest that the concept of human rights needs to be displaced, but to call for a concept that allows local circumstances to be taken into account, to be part of the equation. Note that I am avoiding the word culture. Let me explain my position further.

\section{Against the 'footnote 10' phenomenon}

Anthropologists are used to thinking in terms of binary oppositions: left and right; low and high; nature and culture; raw and cooked; myth and history. Here we are concerned with yet another binary opposition: universalism and relativism. As I have indicated, my position is that one pole cannot exist without the other. This is what Louis Dumont suggested in his analysis of the caste system in India, when he coined the phrase 'encompassment of the contrary' (1979). In this study, Dumont discusses the opposition between hierarchy and equality, and compares the Indian experience to the Western one. The former seems to be governed by hierarchy, the latter by equality. However, Dumont argues, one pole never manages completely to exclude the other; rather, it encompasses it. Thus, in India, the dominant principle may be the 
hierarchical one, but it includes the drive towards equality. By contrast, in the West, the dominant principle may be equality, but this cannot eliminate hierarchical tendencies and practices. In other words, the dominant pole cannot but encompass its opposite. The application to my topic is straightforward: universalism cannot exist without relativism, and vice versa.

This directly follows Hatch's suggestion that ethical relativism presents us with a paradox: even though we cannot live with it, it is not clear how we can avoid it $(1997: 371,373)$. Hatch remarks that he first presented his paper at a session of the American Anthropological Association on the significantly formulated theme of 'Human Rights: Universalism versus Relativism'. He writes: 'Adapting a Derridian argument, the question of human rights and general standards of ethical judgement are never a mere "presence", something to be established in their own right, but exist only in relation to their opposite, which is relativism' (ibid.: 373). As I have said, one pole does not exist without the other. This is simple enough to understand. And yet this basic 'truth' easily gets forgotten.

The title of Hatch's essay 'The Good Side of Relativism', is highly revealing, because it implies that universalism is the dominant pole in the binary opposition, the term that can be taken for granted. It is as if it did not need to be argued for in the debate about the universality (note which word appears again) of human rights. Can you imagine coming across an article entitled 'The Good Side of Universalism'? Such an occurrence is unlikely because the prima facie value of universalism is generally not contested. There is more: universalism can so much be taken for granted that the other pole of the equation, relativism, can get almost totally overlooked. This leads me to what I shall call the 'footnote 10' phenomenon.

A footnote of that number recently appeared in a book from a leading law publisher which contained almost 800 pages of text and materials on international human rights (Wallace 1997). In a work of this length, one might have expected more than a lip-service to the universalism versus relativism debate. However, the one reference to the debate is hidden in a seven-line footnote (the tenth) to the effect that cultural relativism is 'an issue of such depth that it falls beyond the scope of this work' (ibid: p. $x$ ). With this acknowledgement, the book is written as if the universality of the human rights provisions it reproduces raises no issues whatsoever. This is consonant with the dominant attitude in the field. The question of the universality of human rights is of interest to anthropologists and to a few others who take it up at meetings especially convened to discuss it (like the AAA session in which Hatch first 
presented his paper), as if the rest of the world could forget about this fundamental issue. ${ }^{21}$ It cannot.

\section{Recognizing the ubiquity of the debate}

I would go even further and say that the need for relativism is so fundamental that it is bound to crop up in places where we would not expect it. One such place is the European Court of Human Rights.

Anyone familiar with the case-law of the Court will have heard about the doctrine of the 'margin of appreciation'. Through this doctrine, the Court recognizes that national governments can be better placed than itself to appreciate local circumstances and local needs, and thus human rights claims. The OPI case ${ }^{22}$ is one of the many cases where the Court has applied the doctrine. The case involved the seizure and destruction in Tyrol of a film which offended Christian feelings. The question the Court had to decide was whether, in so acting, the Austrian authorities had violated the right to freedom of expression. The Court decided there had been no such violation. It argued:

The Court cannot disregard the fact that the Roman Catholic religion is the religion of the overwhelming majority of Tyroleans. In seizing the film, the Austrian authorities acted to ensure religious peace in that region and to prevent that some people should feel the object of attacks on their religious beliefs in an unwarranted and offensive manner. It is in the first place for the national authorities, who are better placed than the international judge, to assess the need for such a measure in the light of the situation obtaining locally at a given time. In all the circumstances of the present case, the Court does not consider that the Austrian authorities can be regarded as having overstepped their margin of appreciation in this respect (my emphasis).

This represents a standard application of the doctrine of the margin of appreciation. The ironical effect it has to allow states to remain 'off the hook', so to speak, while the aim of the European Convention of Human Rights is to supervise state action, has not been lost on lawyers (Steiner \& Alston 1996: 631-634). But we can look at the doctrine in another light. We can see it as a way for the Court to deal with the 'unspoken' pole in the universalist-relativist equation. The Court does not do so by naming relativism, but by inventing a new expression: 'the margin of appreciation'. The result is the same, in that the doctrine makes it possible for the non-dominant pole to be encompassed in the dominant one. It makes it possible to take into account local circumstances, ie what some would call - arguably, regrettably - culture (see Brems 1997: 162). 


\section{Conclusion}

During the workshop from which this book arose, Peter Fitzpatrick remarked that the universal can never establish itself because it must be approached from the specific. The UN Declaration provides a good example, I think, of what he means. The Declaration pretends to universality, but it was in fact drafted by people who looked at the world from a particular window. Its drafters were addressing a particular situation, which they had experienced and did not want to see repeated. ${ }^{23}$ While they were hoping to achieve the universal, they were doing this from a specific position. The same is true of all human rights conventions: they strive to reach the universal, but address the problem they wish to confront from a particular position. Fitzpatrick talked of a mutual compensation between the two poles, in which each constitutes the other. He was careful to point out that the achieved resolution is not knowledge; rather it is a constant effort to find one's way. I agree with him. This is why I say that the in-between position I advocate is an unstable one and have opted for the image of the pendulum. ${ }^{24}$ Rather than a theory which invites us to choose one of the two poles, we need one which recognizes that neither is tenable without awareness of the other. We may also have to accept that, in practice, we shall remain torn between them.

\section{ACKNOWLEDGEMENTS}

I have developed the argument presented here over the years and especially thank the Centre for Cross-Cultural Research on Women (Oxford), the North-South Coalition (Oslo) and the Centre for Sociolegal Studies (Oxford) for the opportunity to share some of my ideas. I have borrowed the idea that relativism and universalism are unsustainable in isolation from each other from Peter Fitzpatrick, who articulated it at the Sussex workshop on which this book is based. Linda WeilCuriel granted me two interviews and Anouk Guiné provided material on the Koita trial. The European University Institute, Florence, funded a research trip to Paris in June 1995. Richard Wilson and Jane Cowan offered perceptive and challenging comments on an earlier draft. Lysbeth Gehrels edited the text.

\section{NOTES}

1 Traditional African land property, often presented as being communitarian, is a case in point. Vanderlinden (1996, pp. 94-98) shows how such a view 
grossly simplifies the reality, which is arguably more akin to a European model of property than is generally imagined.

2 See for example Dembour 1996: 22-24; Donnelly 1989: 5; Marks 1998: 481-482, 523-514.

3 This research is mainly literature-based, although it includes two interviews with Linda Weil-Curiel in Paris (June 1995 and March 1997) and one with Efua Dorkenoo in London (June 1995).

4 This is exactly the point made by Christine Walley (1997) in a subtle article which urges us not to understand female genital operations in either/or terms.

5 For anthropological references, see for example Boddy 1982; Erlich 1986; Talle 1993.

6 To be noted that international human rights legislation calls for the abolition of female genital mutilation either directly (see article 2(a), for example, of the 1994 Declaration on the Elimination of Discrimination Against Women) or by targetting traditional practices prejudicial to health (e.g. Article 24 (3) of the 1989 UN Convention on the Rights of the Child). Female circumcision makes up the lion's share of the various 'harmful cultural practices' that outrage feminists (Brems 1997: 148).

7 In support of this view, one can observe that the roots of the Universal Declaration of Human Rights lay in the French Revolution (Marks 1998).

8 For details on these and the other cases cited below, see Table 3.1.

9 Winter speaks of October 1982 as the date of this trial (1994: 944), but Lefeuvre-Déotte gives the date as October 1984 (1997: 23).

10 Under French law a partie civile is the individual or an organization representing the interests of the victim(s) in a criminal case. As a party to the case, the partie civile is entitled to its own lawyer(s), whose arguments typically parallel those of the Prosecution.

11 For a transcript of the arguments put forward at a particular trial, see Lefeuvre-Déotte (1997, chapter 1).

12 To give two examples: in Warrior Masks, Alice Walker recounts that she 'wanted to take [the little girls] in [her] arms and fly away with them' (1993: 49); half a century before, the anthropologist de Villeneuve (1939) expressed similar shock, although in a different style.

13 See also the testimony of Fadumo in Abdalla (1982: 105-107).

14 Interestingly the Prosecution's line has been relatively softer, as demonstrated by its lack of action until Bobe Traoré's death made the headlines, its initial satisfaction that excision cases were to be dealt with by correctional tribunals, and its frequent request for sentences against parents to be suspended.

15 The president of the court nonetheless assured that 34 -year-old Teneng Jahate, who had been breastfeeding the youngest of her 8 children during the proceedings, would be freed that night, as he was going to request the application of a rarely used legal mechanism, which allows for the sentence not to start being served until the judgement becomes final.

16 See Newsletter no 14 of the Inter-African Committee on Traditional Practices Affecting the Health of Women and Children (July 1993: 6).

17 This fight does not consist in a criminal strategy only. It also includes an 
education programme, consisting of posters, leaflets and most notably a short, entertaining, and excellently produced film entitled Bintou à Paris.

18 This is consonant with an approach which looks at human rights as having been invented to check the arbitrariness of the modern state.

19 He notes that the Svadharma vision should not be rejected just because it fails to live up to its own standards, as the system of castes and especially the treatment of the untouchables demonstrate. What he says about Svadharma can also be said of the human rights ideology. It is not because human rights are constantly violated that the ideal which they represent should be rejected.

20 For Christoph Eberhard, who works in the wake of Panikkar, what is important is to use a dialogical and pluralistic approach to go beyond (as opposed to stay in-between) the universalist and relativist poles.

21 The parallel with women's rights is striking. Although men cannot exist without women (and vice versa), women's issues tend to be forgotten and relegated to special forums, without ever managing to become mainstream.

22 Otto Preminger Institute vs. Austria, Judgment of 20 Sepember 1994, Series A, No.295-A; (1995) 19 European Human Rights Reports 34.

23 On the impact of the Second World War on the development of the International Bill of Human Rights, see Morsinck 1993.

24 This image has limitations. In particular, it could suggest a mechanical reversal at a definite point from one pole to the next. Of course I do not suggest this.

\section{REFERENCES}

Abdalla, R.H.D. 1982. Sisters in Affliction: Circumcision and Infibulation of Women in Africa. London: Zed Press.

Boddy, J. 1982. Womb as Oasis: The Symbolic Context of Phraonic Circumcision in Rural Northern Sudan. American Ethnologist, 682-698.

Brems, E. 1997. Enemies or Allies? Feminism and Cultural Relativism as Dissident Voices in Human Rights Discourse. Human Rights Quarterly 19, 136-164.

Curzon, L.B. 1979. Furisprudence. Aylesbury: MacDonald \& Evans.

Dembour, M-B. 1996. Human Rights Talk and Anthropological Ambivalence: The Particular Contexts of Universal Claims. In Inside and Outside the Law: Anthropological Studies in Authority and Ambiguity. (Ed.) Olivia Harris. London: Routledge.

de Villeneuve, A. 1937. Etude sur une coutume somalie: Les femmes cousues. Fournal de la Société des Africanistes 7, 15-33.

Donnelly, J. 1989. Universal Human Rights in Theory and Practice. Ithaca: Cornell University Press.

Dorkenoo, E. 1994. Cutting the Rose. Female Genital Mutilation: The Practice and its Prevention. London: Minority Rights Group.

Dumont, L. 1979. Homo Hierarchicus. Le système des castes et ses implications. Paris: Gallimard.

Eberhard, C. 1999. Pluralisme et Dialogisme: Les droits de l'homme dans une 
mondialisation qui ne soit pas uniquement une occidentalisation. La revue du MAUSS semestrielle 13, 261-279.

Erlich, M. 1986. La femme blessée. Essai sur les mutilations sexuelles féminines. L'Harmattan. Préface de Marc Augé.

Favell, A. 1998. Philosophies of Integration: Immigration and the Idea of Citizenship in France and Britain. Houndsmills: Macmillan.

Fitzpatrick, P. 1992. The Mythology of Modern Law. London: Routledge.

Hargreaves, A. G. 1995. Immigration, 'Race' and Ethnicity in Contemporary France. London: Routledge.

Harris, J.W. 1980. Legal Philosophies. London: Butterworths.

Hatch, E. 1997. The Good Side of Relativism. Fournal of Anthropological Research 53, 371-381.

Howard, R. 1993. Social Degradation and Female Self-mutilation in North America. In Human Rights in the 21st Century: A Global Challenge. (Ed.) Kathleen Mahoney. Amsterdam: Nijhoff.

Kumar, C. 1998. South Wind: On the Universality of the Human Rights Discourse. In Human Rights: Universal or Culture Specific. North-South Coalition Information Bulletin No1, 111-150.

Lefeuvre-Déotte. 1997. L'excision en procès: Un différend culturel? France: L'Harmattan.

Lightfood-Klein, H. 1989. Prisoners of Ritual: An Odyssey into Female Genital Mutilation in Africa. New York: Haworth Press.

Lindholm, T. 1998. The Plurality of Normative Traditions and the Need for Cross-cultural Legitimacy of Universal Human Rights. In Human Rights: Universal or Culture Specific. North-South Coalition Information Bulletin No. 1, 10-46.

Lord Lloyd of Hampstead and M.D.A. Freeman. 1985. Lloyd's Introduction to Furisprudence. London: Stevens and Sons.

Marks, S.P. 1998. From the 'Single Confused Page' to the 'Decalogue for Six Billion Persons': The Roots of the Universal Declaration of Human Rights in the French Revolution. Human Rights Quarterly 20, 459-514.

Morsink, J. 1993. World War II and the Universal Declaration. Human Rights Quarterly 15(2), 357-405.

Panikkar, R. 1982. Is the Notion of Human Rights a Western Concept? Diogenes $120,75-102$.

Parker, M. 1995. Rethinking Female Circumcision. Africa 65(4), 506-523.

Pollis, A. and P. Schwabb (Eds.). 1980. Human Rights: Cultural and Ideological Perspectives. New York: Praeger.

Steiner, H. \& P. Alston. 1996. International Human Rights in Contex: Law, Politics and Morals. Oxford: Oxford University Press.

Summerfield, H. 1993. Patterns of Adaptation: Somali and Bangladeshi Women in Britain. In Migrant Women: Crossing Boundaries and Changing Identities. (Ed.) Gina Buijs. Oxford: Berg.

Talle, A. 1993. Transforming Women into 'Pure' Agnates: Aspects of Female Infibulation in Somalia. In Carved Flesh/Cast Selves: Gendered Symbols and Social Practices. (Eds.) Vigdis Broch-Due, Ingrid Rudie and Tone Bleie. Oxford: Berg.

Thomas, L.M. 1996. 'Ngaitana (I will circumcise myself)': The Gender and 
Generational Politics of the 1956 Ban on Clitoridechtomy in Meru, Kenya. Gender and History 8(3), 338-363.

Toubia, N. and A. Rahman. 2000. Female Genital Mutilation: A Guide to Worldwide Laws and Policies.

Touré, C. 1984. Des femmes africaines s'expérimentent. In Les Mutilations $d u$ Sexe des Femmes d'Aujourd'hui en France. Paris: Editions Tierce.

Vanderlinden, J. 1996. Anthropologie juridique. Paris: Dalloz.

Walker, A. and Prathibha P. 1993. Warrior Masks. Female Genital Mutilation and the Sexual Blinding of Women. New York: Harcourt Brace.

Wallace, R. 1997. International Human Rights: Text and Materials. London: Sweet \& Maxwell.

Walley, C.J. 1997. Searching for 'Voices': Feminism, Anthropology, and the Global Debate over Female Genital Operations. Cultural Anthropology 12(3), 405-438.

Winter, B. 1994. Women, the Law, and Cultural Relativism in France: The Case of Excision. Signs 19(4), 941-974. 